\title{
CAUSATION AND DISPOSITIONS: TOWARDS A SEMANTIC CHARACTERISATION FOR THE FRENCH CAUSATIVE VERB LAISSER
}

\author{
Marta Donazzan $^{*}$, Clémentine Raffy ${ }^{* * *}$ \& Klaus von Heusinger ${ }^{* * * 1}$
}

\begin{abstract}
The French causative verb laisser can enter two different constructions: a monoclausal one resembling the faire-infinitive construction (Kayne 1975, Alsina 1992, Guasti 1996, Folli \& Harley 2007) and a biclausal one. While differences in interpretation between these two constructions have been pointed out (Kayne 1975, Enghels \& Roegiest 2012), the link between structure and conceptual representation has not been clearly defined yet. In this paper, we tackle the syntax and semantics of causative laisser adopting as a background Talmy's (1988) force dynamics model of causation. We further show that the link to the selectional restrictions of the causative verb can be made by considering forces as dispositional causal properties (Fara 2001), that is, properties that become relevant with respect to the role of an entity in a causal chain.
\end{abstract}

Keywords: causation, syntactic causatives, force dynamics, dispositions

\section{Introduction}

The French causative verb laisser realises its embedded verb in two possible ways. The pair of intransitive and transitive predicates in (1) exemplifies what we will call the pre-V pattern: the logical subject of the embedded verb is realised in pre-verbal position. The two sentences in example (2) exemplify what we will call the post-V pattern: the logical subject of the embedded verb is realised in the post-verbal position when the verb is intransitive, and as the complement of a preposition when the post-verbal slot is occupied by the direct object of a transitive verb. ${ }^{2}$

a. Marie a laissé Pierre dormir.

pre-V pattern

Marie laisser.PF Pierre sleep

'Marie let Pierre sleep.'

b. Marie a laissé Pierre manger le gâteau.

Marie laisser.PF Pierre eat the cookie

'Marie let Pierre eat the cookie.'

\footnotetext{
*Université de Nantes, marta.donazzan@univ-nantes.fr.

*** Universität zu Köln, craffy@uni-koeln.de.

*** Universität zu Köln, klaus.vonheusinger@uni-koeln.de.

${ }^{1}$ We are grateful to the audience of the workshop "The Syntax and Semantics of Internal Arguments" at the University of Bucharest, where this work was first presented, for their helpful comments on our work. In particular we would like to thank Alina Tigău for editing this volume, Martin Becker, Christoph Schwarze, Bridget Copley, and one anonymous reviewer for their helpful comments. The research has been supported by the German Research Foundation (DFG) as part of the project "Composing events in Romance causative constructions and the semantics of causation" (Project-ID 361344414) at the University of Cologne, Department of German Language und Literature I, Linguistics (http://idsl1.phil-fak.uni-koeln.de/dfg-project. html).

2 Throughout the paper we use the following abbreviations in the glosses for French: PF - perfective aspect forms (French passé composé); IMP - imperfective aspect forms (French indicatif présent and imparfait); INF - infinitive; CL - clitic pronoun; P - preposition; ACC/DAT - accusative/dative case; SG/PL - singular/plural.
}

Bucharest Working Papers in Linguistics XXII, 1, 55-75, e-ISSN 2392-8093, ISSN-L 2069-9239

DOI: 10.31178/BWPL.22.2.3 
(2) a. Marie a laissé dormir Pierre.

Marie laisser.PF sleep Pierre

post-V pattern

'Marie let Pierre sleep.'

b. Marie a laissé manger le gâteau à Pierre.

Marie laisser.PF eat the cookie P Pierre

'Marie let Pierre eat the cookie.'

In recent years, research on causative constructions in French has tended to focus on the structures featuring the verb faire 'make' and its cognates across Romance languages (Kayne 1975, Alsina 1992, Guasti 1996, Folli \& Harley 2007), but in this paper we will show that laisser causatives challenge our understanding of the interface of language and cognition in their own interesting way. Here we will mention two relevant issues.

The first point of interest is the semantics of the causative verb. If the verb laisser should be understood as a causative operator, it encodes a complex relation which is not appropriately described by the all-purpose CAUSE relation familiar to lexical semantics since Dowty (1979). Consider, as a start, the following pair of sentences:
a. Jean a fait nettoyer la salle de bain à Lucie.
'Jean made Lucy clean the bathroom.'
b. Jean a laissé nettoyer la salle de bain à Lucie.
'Jean let Lucy clean the bathroom.'

Both sentences in (3) encode a causal relation: in both cases, Jean is responsible, by acting in some way, for the cleaning by Lucie. Yet, intuitively we know that makelfaire and let/laisser are not synonymous, and a single CAUSE-operator would not allow us to differentiate between (3a) and (3b). Additionally, philosophical approaches to causation have presented it as a counterfactual relation between two events: "if A had not happened, then B would not have happened" (Lewis 1974). This principle allows us to claim that both sentences in (3) are indeed causative: if it was not for Jean's action, then Lucy would not have cleaned the bathroom. But here again, it fails to address the difference between (3a) and (3b).

A principled way to discriminate between the two causal relations is offered by the force-dynamic theory of causation, originally conceived by Talmy (1988), which we take as a background in this paper. In his discussion on force dynamics, Talmy (1988: 50) argues that several primitives fall under the causative umbrella: causing, letting, helping and hindering. While both causing and letting are, for Talmy, interactions rooted in the opposition between two entities, they differ from one another in that they encode different types of interactions of forces.

In Talmy's force dynamic model, force-entities have intrinsic tendencies (i.e. forces) either towards action or towards rest, and the interaction of these tendencies with one another gives rise to different causal relations. In this framework, causing expresses a relation in which one of two opposing forces overcomes the other: that is, (3a) conveys that Lucie and Jean had different tendencies with respect to the cleaning of the bathroom, and that Jean, who has a tendency towards cleaning, overcomes Lucie tendency against it. 
Letting, on the other hand, expresses the opposition in an opposing way: Lucy has a tendency towards cleaning, while John is understood as being against it. Furthermore, a verb such as laisser may encode two different scenarios: a cessation of impingement situation, in which the blocking force opposed by Jean is removed, thus leading to the occurrence of the result, and a leave alone situation, in which the opposing force embodied by Jean remains remote, thus allowing Lucie's tendency to be realised. In both scenarios, we observe that it is not the action but rather the absence of action by one of the two entities that allows for the resultant state to be reached: one of the two entities involved in a letting situation must possess the ability to prevent the resultant state from happening, acting as a would-be preventer (McGrath 2005) for the final event, which is reached only if this preventer does not act.

Such configurations have thus been characterised as instances of causation by omission. Causation by omission appears to be dilemma for dependency theories of causation, in which the notion of logical, probabilistic or counterfactual dependency plays a major role. Notably, David Lewis' (1974) philosophical approach to causation defines it as a counterfactual relation between events, in which an event $B$ could not have occurred without the occurrence of an event A. If this is the only way that "causation" happens, how can the absence of an entity or of an event be a cause? Independently of the theoretical framework, the problem of identifying a cause in an omission is that of overgeneralisation: given an event $e$, there are an infinite number of non-events that can be its cause. In the scenario depicted by (4), it is clear that the two robbers do not act on the hostage - their attention is not even on him. So why is it that they are still interpreted as the primary source for the hostage escaping, rather than, say, the hostage's desire to survive? Or, even, any other event that did not happen at the same time (say, the Queen of England not dying)?

(4) Les ravisseurs étaient tellement occupés à se disputer qu'ils ont laissé s'échapper leur otage.

'The kidnappers were so busy arguing that they let their hostage escape.'

McGrath (2005) solves this problem by restricting possible causes through a "normative component", which is given by normality, defined in the following way: "it is normal for $\mathrm{x}$ to $\varphi$ iff $\mathrm{x}$ is supposed to $\varphi$ " (McGrath 2005: 138). In the scenario set up by (4), the situation is thus abnormal. It is normal for kidnappers to keep their hostage under control, and they are supposed to do so. Considering a normal situation, the kidnappers are thus would-be preventers of the escape of the hostage, and yet the hostage managed to escape, as they do not behave in the expected way.

Summing up, previous accounts suggest that laisser should be described as a causative verb that involves an intensional component, either, when its meaning is modelled as an interaction of forces, in the tendency expressed by it subject (a would-be preventer), or by the notion of normality, if it is analysed as an instance of causation by omission.

The second issue raised by laisser concerns the relation between syntax and semantics, more precisely the possibility of realising the two distinct syntactic structures in (1) and (2) above, and their relation with interpretation. It has been claimed, since at 
least Kayne (1975), that the pre- and post-V patterns are associated to distinct and subtly different interpretations. Thus, Kayne (1975: 222) observes (our translation from French):

If one considers their semantic interpretation, the assignment of distinct deep structures to the minimal pairs: elle a laissé Jean partir [ laisser NP S] and elle a laissé partir Jean [laisser [S]) ('she let Jean leave') is not an artificial trick, as the two constructions, in fact, are not necessarily synonymous. Thus, the following sentences are generally considered as having distinct interpretations:

(a) le gardien a laissé le prisonnier s'échapper

(b) le gardien a laissé s'échapper le prisonnier

('the guard let the prisoner run away')

The first one seems to imply a certain degree of complicity, or a deliberate neglect from the guard. That's not the case of the second one.

While the observation seems a robust one in the literature (see also Borel 1972 and, more recently, Enghels \& Roegiest 2012), it is still not clear what the scope (semantic or pragmatic) of this interpretive distinction is, and what precisely it is due to. Our aim in this paper will be to outline a hypothesis about the semantics of laisser which may help understanding the interpretation of laisser-causatives at the syntax-semantics interface. In a nutshell, our take on it is the following. We consider laisser as a causative verb expressing a type of relation which is conceptually dynamic in that it brings about change, while at the same time being a non-eventive one: the dynamics of laisser is originated by (the attribution of) intentions rather than by physical forces. We propose to characterise intentions as sub-types of dispositional properties ascribed to the entities in the causal relation, and we show that this hypothesis may help us account for the thematic selection of the causative verb.

The paper is organised as follows. In section 2, we present the relevant facts about the syntax and semantics of laisser-causatives, and quickly review previous analyses. Section 3 outlines our proposal: we provide a lexical entry for laisser (3.1) and then, in section 3.2, we tackle the issue of the argument selection of this verb in the causative construction: we present new empirical data concerning the restrictions on the thematic arguments of laisser, and show that they can be accounted for when interpreting laisser in a dynamic model. In section 3.3, we then argue that the thematic positions of laisser should best be characterised by making use of dispositional properties. In section 4 , we then provide a partial conclusion and point to further research.

\section{The syntax and semantics of laisser-causatives}

\subsection{The two patterns}

The two structures exemplified by (1) and (2) above have been analysed in different ways in the literature. The pre- $\mathrm{V}$ pattern has been interpreted roughly as a control structure. Clitic placement shows that the subject of the infinitive cliticises to laisser, while the object of the transitive verbs in the lower clause cliticises to the lower 
predicate (5b), a fact which suggests a bi-clausal analysis. Laisser is generally compared in this respect to perception verbs such as voir 'see' in French (6):
a. Marie a laissé les enfants manger la pizza. Marie laisser.PF the children eat.INF the pizza 'Marie let the children eat the pizza.'

b. Marie les a laissés la manger

Marie CL.ACC.PL laisser.PF CL.ACC.SG eat.INF

'Marie let them eat it.'

(6) a. Marie a vu les enfants manger la pizza.

Marie see.PF the children eat.INF the pizza

'Marie saw the children eat the pizza.'

b. Marie les a vus la manger

Marie CL.ACC.PL voir.PF CL.ACC.SG eat.INF

'Marie saw them eat it.'

In the post-V construction, on the other hand, when the verb of the subordinate clause is transitive, laisser realises its subject as the complement of a preposition. Clitic placement shows that both the object of the verb and the oblique subject must cliticise to the matrix laisser (7b vs. 7c), a fact which suggests a monoclausal analysis for the structure, along with what has been proposed for the causative verb faire, cf. (8) (Rizzi 1978)

a. Marie a laissé manger la pizza aux enfants.

Marie laisser.PF eat.INF the pizza P-the children

'Marie let the children eat the pizza.'

b. Marie la leur a laissé manger.

Marie CL.ACC CL.DAT laisser.PF eat.INF

c. *Marie leur a laissé la manger.

Marie CL.DAT laisser.PF CL.ACC eat.INF

(8) a. Marie a fait manger la pizza aux enfants.

Marie make.PF eat.INF the pizza P-the children

'Marie made the children eat the pizza.'

b. Marie la leur a fait manger.

Marie CL.ACC CL.DAT make.PF eat.INF

c *Marie leur a fait la manger.

Marie CL.DAT make.PF CL.ACC eat.INF

Because of the facts in (7) and (8), research on laisser-causatives in French has indeed been mostly restricted to limited comparisons of these structures with fairecausatives. The reason for this neglect is that the analysis of faire-constructions is itself still subject to debate. A proposal which has received credit in the literature sees faire as forming a complex predicate with the following VP (Guasti 1996, Folli \& Harley 2007). ${ }^{3}$

\footnotetext{
${ }^{3}$ A complex predicate is formed when two or more predicative elements enter a relation of co-predication. Each element adds arguments to a monoclausal predication, which means that there is no embedded clause at the level of syntax (Butt 1995, 2010).
} 
The behaviour of laisser in (5) and (7) then prompted some scholars to propose two distinct lexical heads for this verb (Abeillé et al. 1997) which would lexicalise either a control predicate similar to that of perception verbs (in the case of the pre-V pattern) or a causative light- $\mathrm{v}$ similar to faire (for the post-V pattern). This line of analysis seems to be enforced also by data on the diachronic development of faire. As remarked by Martineau (1990), while in modern standard French only the post-V pattern is judged grammatical, in earlier phases faire also displayed a pre-V pattern, and still marginally retains this pattern with clitic arguments (see also the discussion in section 2.2).

\subsection{Issues of interpretation}

As regards the interpretation of the two constructions exemplified by (1) and (2), two facts must be discussed, which concern (i) the semantic or pragmatic nature of the difference in interpretation remarked by earlier scholars and (ii) the relation between form and interpretation.

Here again the literature on faire can serve as a starting point. Studies that aimed at answering the second issue and that derive the interpretation of faire-causatives from syntactic constraints tend to attribute to monoclausal constructions such as (8) an interpretation described in terms of "affectedness", by which the Causer's "causation of the event described by the infinitive verb is directed toward the [Causee] or, equivalently, the [Causee] is affected by the event caused" (Guasti 1996: 296). This flavour of affectedness of monoclausal faire, which, in Guasti's (1996) analysis, is due to the casemarking of the Causee as a benefactive argument, is however weakened by the contrast with the limited cases where faire admits a biclausal structure. As mentioned before, the pre-V pattern is judged utterly ungrammatical by speakers of modern standard French if the arguments of the embedded verb are realised as full DPs (cf. 9a-b). However, the pre$\mathrm{V}$ pattern appears to be still marginally accepted when the subject is a clitic pronoun. The contrast between the two patterns can thus only be appreciated in pairs such as (10a-b).

(9) $\quad$ a. *Il a fait Pierre manger les épinards. he make.PF Pierre eat.INF the spinach

b. Il a fait manger les épinards à Pierre. he make.PF eat.INF the spinach $P$ Pierre 'He made Pierre eat spinach.'

(10) a. Il l'a fait manger les épinards. he CL.ACC make.PF eat.INF the spinach

b. Il lui a fait manger les épinards. he CL.DAT make.PF eat.INF the spinach 'He made him eat spinach.'

Authier \& Reed (1991) notice a semantic difference between the two types of sentences, and claim that while in (10a) the Causee is understood as being coerced into eating spinach, (10b) is neutral to coercive implications. In their analysis, then, affectedness or coercion is a marked interpretation which is attributable rather to the less acceptable pre-V pattern. Abeillé et al. (1997) also discuss the different interpretations of 
the two patterns of faire, and suggest that each must be encoded in one of the lexical entries of the verb: the faire in (10a) is likened to French forcer 'to force', whereas the faire in (10b) is an auxiliary-like, semantically bleached causative verb. They make the further point that, in the case of the verb faire that they associate to the control structure (10a), the two concepts of "coercion" and "control" should be kept distinct. The control of the Causer over the Causee must be always implied for this kind of verb, and therefore only coercion may be subject to variation in degree. Coercion effects then depend on the relation of power between Causer and Causee, and are essentially a pragmatic phenomenon. This is illustrated, in their mind, by the case of psych-verbs, which do not accept coercion by an external agent, cf. (11), from Abeillé et al. (1997: 66). The sentence (11a) is ruled out, since the lexical entry of faire in the pre-V pattern enforces a coercive interpretation. Conversely, (11b) exemplifies the post-V pattern, the monoclausal construction which is not subject to the same constraints, as the causative verb has no coercive meaning in itself.

\#Faites-les aimer Proust!
make-CL.ACC love.INF Proust
F. Faites-leur aimer Proust!
make-CL.DAT love.INF Proust
'Make them love Proust!'

As regards laisser, for which we must suppose a different lexical entry, affectedness or coercive effects do not affect felicity in the same way. Psych-verbs are fine in both monoclausal and biclausal constructions - which is expected, as intuitively the type of causal relation expressed by laisser does not imply coercion. On the other hand, as we have seen from Kayne's observation (which is generally corroborated by native speakers), a certain degree of control (or intentional action) by the Causer seems indeed to tease apart the interpretation of the two constructions, although the contrast should be phrased in a different way.

We have seen above that Kayne (1975: 222) talks about complicity or neglect. Authors who focus rather on the lexical semantics of laisser-verbs in terms of causative relations tend to associate the distinct interpretations of the two patterns to a parameter that encodes the involvement of the subject of laisser (let's call it the laisseur). Following Soares da Silva's $(1998,2003,2004)$ and Maldonado's (2007) analysis of Spanish and Portuguese laisser-verbs, and based on the contextual interpretation of laisser constructions in a corpus study, Enghels \& Roegiest (2012) distinguish at least two different meanings of causative laisser, which they dub "allow" (permitir) and "not oppose" (no oponerse). The former is roughly associated to the pre-V pattern, and the latter to the post-V pattern. The two examples below illustrate the opposition for the unaccusative verb mourir 'die'. The example (12a) features a pre- $\mathrm{V}$ pattern, and laisser is quite naturally interpreted as a verb of permission (the laisseur decides to allow the event to happen); the construction in (12b) is an example of post-V pattern, and we evince from the text that the fire has died out because the laisseur simply did not act. 
(12) a. Isabelle, tu n'aurais tout de même pas voulu qu'Ignacio laisse sa famille mourir de faim. (Bourdet, Le sexe faible, 1931) 'Isabelle, you certainly wouldn't wish that Ignacio let his family die of starvation.'

b. Elle laissait mourir le feu, et, à mesure que la pièce devenait plus froide, elle traînait sa chaise vers l'âtre, ses pieds touchaient presque la cendre. (Mauriac, Nid de vipères, 1932)

'She let the fire die out, and, as the room was getting colder, she dragged her chair towards the fireplace, her feet almost touching the ashes.'

(Enghels \& Roegiest 2012: 111, ex. (38))

Enghels \& Roegiest (2012)'s characterisation must be understood within the theoretical framework set by Talmy's force dynamics, which we briefly expounded in section 1. Considering the dynamics of forces that characterises the causal relation, the notion of "control" also has a different definition, as it "should thus be understood in terms of which participant, the causer or the causee, is the entity which is more responsible for the execution of the caused event" (Enghels \& Roegiest 2012: 3). In this respect, they notice a reverse correlation between the degree of control of the Causer and that of the Causee: to a high degree of control of the Causer corresponds a lower level of independence and control of the Causee in the subordinate event, and vice versa.

To summarise, previous accounts left several issues unanswered. First, one may wonder whether one needs to assume two semantically distinct lexical entries for laisser, or the two interpretations rather depend on pragmatic facts. And if so, is there a construction which is marked, and one which is neutral for laisser as well? In the following, we will argue that, granting the same lexical entry for causative laisser, the interpretational difference indeed tends to correlate with other grammatical features, the most relevant being the thematic selection of the verb.

\section{Towards a semantics for laisser causatives}

We start from the hypothesis that laisser is a type of causative verb, in the sense that it encodes a relation between two entities that are each seen as generating a force oriented in some direction with respect to the realisation of a result.

At the interface with syntax, we may characterise the verb laisser and the embedded verb as a complex structure, which can be represented as a case of indirect causation. A first working representation of the structure is given in (13): the subject of laisser (the laisseur) is not directly responsible for the event denoted by the embedded verb to happen, in so far as the embedded verb selects its own thematic argument (the laissé).

$$
\begin{aligned}
& \text { Jean a laissé (Marie) lire (Marie) } \\
& \mathrm{e}_{1}, \mathrm{e}_{2} \text {.laisseur }\left(\mathrm{e}_{1}, \mathrm{~J}\right) \& \operatorname{LAISSER}\left(\mathrm{e}_{1}, \mathrm{e}_{2}\right) \& \operatorname{READ}\left(\mathrm{e}_{2}\right) \& \text { laissé }\left(\mathrm{e}_{2}, \mathrm{M}\right)
\end{aligned}
$$


The definition in (13) describes LAISSER as a causative verb, encoding a sub-type of the all-purpose CAUSE relation, on par with predicates like faire or make. We have seen, however, that each of these verbs encodes a causative relation with its own interpretation, and we will see that they also have their own distinct thematic selection. In this sense, the thematic characterisation of the arguments of laisser (the laisseur and the laissé) has been intentionally left vague for the time being. The task in the following section will be precisely to refine our definition on this point, while providing a lexical entry for the causative verb that specifies its contribution to the hosting sentence.

\subsection{The contribution of laisser as a causative verb}

Cognitive semantics studies on causative verbs define $L E T$-type verbs as involving complex dynamics of forces, characterised by the ability of the subject of LET to be a potential controller of the event, and its final resolution not to control it (Wolff \& Thorstad 2016). In plain terms, one important component of the meaning of a sentence like John let the children play is that John could have prevented the children from playing and he chose not to do so, or in that specific instance, he could not. Recall from our discussion in section 1 that the subject of laisser is understood as a would-be preventer (McGrath 2005): causative verbs of this type have thus been defined double-prevention verbs in the sense that they express a dynamic by which the initiator (the laisseur) is set to prevent a possible prevention of the embedded event. This feature is responsible for a counterfactual flavour in laisser-causatives, which realise configurations where the laisseur has the ability to prevent the laissé from realising its tendency towards the result, but this potential prevention is not carried out. ${ }^{4}$

To sum up, according to the force-dynamic characterisation the felicitous use of laisser requires at least three conditions to be realised: (i) the laissé has a tendency towards the result expressed by the embedded VP; (ii) the laisseur has the ability to prevent the laissé to VP (it is a would-be preventer); (iii) the laisseur does not prevent the laissé from VP-ing. We propose to encode these three features in the lexical entry of laisser in (14), where $\left\{\mathrm{NP}_{\mathrm{P}} \mathrm{VP}\right\}$ stands for both the pre- $\mathrm{V}$ and the post- $\mathrm{V}$ patterns.

(14) Given a situation $S$ where L1=laisseur and L2=Laissé:

$\mathrm{NP}_{\mathrm{L} 1}$ laisser $\left\{\mathrm{NP}_{\mathrm{L} 2} \mathrm{VP}\right\}$ : (i) L2 is understood to have a tendency towards VP in S

(ii) presupposes that L1 may apply a force $\mathrm{F}$ to prevent L2 from VP

(iii) asserts that $\mathrm{L} 1$ prevents the force $\mathrm{F}$ to apply

The three components of meaning discussed above are attributed to the predicate laisser in definition (14) as three pieces of information of distinct nature. First, Def (14) states that the laissé is understood as having a tendency for the result in $\mathrm{S}$ (see also Wolff

\footnotetext{
${ }^{4}$ We might say that the causal relation has a counterfactual flavour, which recalls philosophical approaches describing causation as a counterfactual relation between two events (Lewis 1974): A is the (direct) cause of $\mathrm{B}$ only if B would not have happened without A. The case of laisser, however, is somehow different, as it is the absence of prevention that needs to happen in order for the embedded event to occur.
} 
\& Song 2003). We consider this component of meaning as a conventional implicature of laisser, which follows from its lexical content and can be cancelled only by questioning the meaning of the verb. Thus, in the context set up by (15), speaker B questions the attribution of a tendency towards doing the ironing that the verb laisser implicates in virtue of its lexical meaning.

(15) (Dad coming home seeing his teen daughter ironing:)

A : Dis donc, maman t'a laissé faire le repassage?

'I say, did mum let you do the ironing?'

B : Elle ne m'a pas laissé le faire, elle m'y a forcé, je ne lui ai surtout pas demandé!

'She didn't $L E T$ me do that - she forced me, I definitely didn't ask to!'

The truth of the conventional meaning of laisser (that his daughter had a tendency to do the ironing) is a precondition of properly using laisser to assert what the father says. This leads us to believe that what is at play in (15) is a conventional implicature. Conventional implicatures are "entailed by lexical and constructional meanings but distinct from the regular at-issue content of the sentence" (Potts 2015). In that sense, they are responsible for the infelicity of a statement in a way that reminds presuppositions (Davis 2019). However, if it is false in the situation $S$ that the daughter had a tendency to do the ironing, the question Did mum let you do the ironing? is improper; answering either "Yes" or "No" implies the existence of a tendency of the laissé to do the ironing, and the only escape hatch is then to question the conventional meaning of laisser altogether.

The dynamics of the laisser configuration further breaks down into a presupposition and an assertion in its lexical entry. The presupposition (14.ii) captures the felicity conditions of (16a vs. 16b): the utterance is felicitous only if the laisseur is supposed to be able to prevent the laissé from doing something. In a situation $\mathrm{S}$ compatible with our knowledge of the world, this potential ability is plausibly attributed to the torturers in (16a), but less likely to the victim in (16b). The usual semantic tests apply: the presuppositional nature of this piece of meaning is confirmed by its not being affected in negative environments and in questions, hence the infelicity of (17a) and (17b).

(16) a. Les tortionnaires ont laissé la victime boire une gorgée d'eau the torturers laisser.PF the victime drink a sip of water 'The torturers let the victim drink a sip of water.'

b. \#La victime a laissé les tortionnaires boire une gorgée d'eau the victim laisser.PF the torturers drink a sip of water

(17) a. \#La victime n'a pas laissé les tortionnaires boire une gorgée d'eau the victim laisser.PF.NEG the torturers drink a sip of water

b. \#Est-ceque la victime a laissé les tortionnaires boire une gorgée Q the victim laisser.PF the torturers drink a sip d'eau?

of water 
Finally, when using laisser the speaker asserts that this possibility to prevent has not been put into use by the laisseur. Note however that the assertive content concerns only the behaviour of the laisseur, but says nothing about whether the laissé finally VPs or not. In fact, as (18) shows, whether the expected result is reached or not is most often not guaranteed:

(18) Jean a laissé les enfants jouer, mais finalement ils étaient tellement épuisés qu'ils ont préféré aller se coucher.

'Jean let the children play, but they were so exhausted that finally they opted for going straight to bed.'

\subsection{Characterising argument selection}

Having characterised the contribution of the causative verb laisser in terms of presuppositional and assertive context, we should now tackle its selectional properties. The theoretical characterisations and the intuitions about the different degrees of control expounded in section 2.2 may be grounded in grammatical terms if one looks more closely at the thematic selection of the two predicates of the construction.

In the following discussion, we characterise the subject position of laisser and of the embedded verb by taking Dowty's (1991) notion of proto-agentive role as a starting point. A proto-role is a position that triggers a cluster of entailments for the entity occupying it. In our discussion of the preceding literature, we focused on examples of laisser-constructions where both participants are proto-agents, i.e. animate entities which may be deemed volitional and self-energetic. If we take agency as a semantic feature relevant for thematic selection, however, we may note that volitionality and the ability of autonomously exert energy are not necessary requirements for the thematic selection of laisseur and laissé. Different studies have shown that the forces that originate a dynamic configuration may be conceptualised as having different sources, such as physical or mental acts (Wolff 2003), dispositional tendencies (Mumford \& Anjum 2013) or even social pressures (Copley \& Harley 2015). Data appear thus to be more complex, and yet, to the exception of Enghels \& Roegiest (2012) corpus-based review, a comprehensive picture has not been attempted so far in the relevant literature. The general observation is that there seem to be specific constraints driving the acceptability of laisser-causatives on the whole, and of each of the two positions for the laissé they allow. In the following section, we thus attempt at a review which can be taken as a heuristic for characterising the thematic selection of laisser within the causative construction. Using the characterisation of the proto-agentive role as a key for interpreting the data, we get an articulated picture.

(i) some constructions are always unacceptable, regardless of pattern

Non-acceptable structures typically involve Causers that embody natural forces, such as the wind (19) or the waves (20), which are those that are typically assigned the thematic role of CAUSER by lexical causative verbs and make-causative light-v (see e.g. Folli \& Harley 2007). These are self-energetic entities, but also non-volitional ones. 
(19) a. \#Le vent a laissé les arbres rester debout

the wind laisser.PF the trees stand.INF upright

b. \#Le vent a laissé rester debout les arbres

(20) a. \#Les vagues ont laissé les bateaux approcher.

the waves laisser.PF the boats approach

b. \#Les vagues ont laissé approcher les bateaux.

the waves laisser.PF approach the boats

Also, derived event nominals (such as débouchage 'unplugging') seem to be bad subjects for laisser.
\#Le débouchage de la baignoire a laissé couler l'eau.
the unplugging of the tub laisser.PF flow.INF the-water

We notice however that force-generating Causers may be acceptable in a "reduced" causative structure, where laisser is followed by a non-eventive complement clause, see (19) vs. (22). Here, the phrase [les arbres debout] is a stative predicate (presumably a Small Clause) $)^{5}$. The structure is similar, but not identical, to those structures where the stative/result predicate is expressed by an AdjP or a PP, as in (23), and laisser would be translated by "leave" in English.

(22) Le vent a laissé les arbres debout.

the wind laisser.PF the trees upright

'The wind left the trees upright.'

(23) a. Jean a laissé les clés sur la table.

Jean laisser.PF the keys on the table

'Jean left the keys on the table.'

b. Laisse-moi tranquille!

laisse me quiet

'Leave me alone!'

The grammaticality difference between (19) and (20), on the one hand, and (22) and (23) on the other hand shows that it is necessary to consider the interpretation of laisser within the causative structure, in order to understand the constraints on the argument selection of the verb. Let's express this descriptive generalisation as in GEN1:

GEN1: Non-volitional force-generating entities (CAUSERS) are excluded as laisseurs, i.e. as subjects of laisser in causative constructions.

\footnotetext{
${ }^{5}$ Harley \& Folli $(2005,2008)$ point out a similar phenomenon with the consumption verb eat in English, which can take both Agents or Causers as subjects. However, when the subject of eat is a CAUSER, eat requires a Small Clause as its complement in order for the sentence to be felicitous, much like laisser. According to them, this hints at the presence of a VCAUSE instead of a VDO.
} 
(ii) some constructions are always acceptable, regardless of the pattern

In this case, the laisseur is typically interpreted as a volitional agent. This includes the case where both laisseur and laissé are expressed by NPs denoting entities interpreted as volitional AGENTS, as in (24), and most notably (25), where each boat is crucially interpreted as driven by a volitional mind, but also cases where the laissé is a nonvolitional entity, as in (26).

(24) a. Jean a laissé les enfants jouer Jean laisser.PF the children play.INF

b. Jean a laissé jouer les enfants Jean laisser.PF play.INF the children

(25) a. La capitainerie de port a finalement laissé les bateaux approcher the authority of port eventually laisser.PF the boats approach.INF

b. La capitainerie de port a finalement laissé approcher les the authority of port eventually laisser.PF approach.INF the bateaux boats 'The port authority eventually let the boats approach.'

(26) a. Le médecin a laissé la perfusion agir avant de mesurer the doctor laisser.PF the infusion act.INF before to measure.INF la tension. the blood pressure

b. Le médecin a laissé agir la perfusion avant de mesurer the doctor laisser.PF act.INF the infusion before to measure.INF la tension. the blood-pressure 'The doctor let the infusion have effect before checking the blood pressure.'

We summarise these descriptive results in GEN2:

GEN2: Volitional force-generating entities (AGENTS) are always acceptable as laisseurs, i.e. as subjects of laisser in causative constructions.

(iii) some constructions seem to be less acceptable with pre-V causee

The concerned examples generally feature Causers denoting entities that do not trigger any typical proto-agentive entailment in the subject position, in the sense of Dowty (1991): entities that are not volitional nor autonomously generating force, such as the curtains in (27).

(27) a. Les rideaux laissent entrer la lumière. the curtains laisser.IMP enter.INF the light 
b. ??Les rideaux laissent la lumière entrer. the curtains laisser.IMP the light enter.INF 'The curtains let the light come in.'

The laissé, in this case, is also a non-agentive entity, but it seems to be one that is capable of autonomous movement at least to some degree. So, the light in (27) appears to be a possible laissé, as light is somehow seen as spreading autonomously through the atmosphere, and is expected to enter rooms if nothing is preventing it from doing so. This is indeed the most natural interpretation, favoured by (27a). The sentence (27b), while still acceptable, seems to require a slightly different context, one where the light is endowed with a particular design or force. Speakers provided very specific contexts, such as a situation where a flash of light (driven by a self-revealing God, for instance) is pushing on the curtains to enter the room.

We remark the same contrast in the reverse situation, i.e. when the laisseur is agentive and the laissé is interpreted as acting non-volitionally. The pre-V pattern seems to be felicitous in a situation where the laisseur is understood as opposing a strong obstacle for the laissé to VP: so, (29b) is more acceptable than (28b), as the context provides a clue for the fact that the nurse is opening the curtains in order for the light to finally rush in.

(28) a. Quand l'infirmière est entrée dans la chambre ce matin, elle a ouvert les rideaux pour laisser entrer la lumière du jour.

b. ?Quand l'infirmière est entrée dans la chambre ce matin, elle a ouvert les rideaux pour laisser la lumière du jour entrer.

'When the nurse entered the room this morning, she opened the curtains to let the daylight in.'

(29) a. L'infirmière est entrée dans la chambre. Il faisait si beau dehors qu'elle a ouvert les rideaux pour laisser entrer la lumière.

b. L'infirmière est entré dans la chambre. Il faisait si beau dehors qu'elle a ouvert les rideaux pour laisser la lumière entrer.

'The nurse entered the room. It was so sunny outside that she opened the curtains to let the light in.'

These intuitions are also found in sentences in the imperative. The sentence in (30) is the catchphrase of a recent ad campaign for a famous furniture store in France:

(30) a. Laissez entrer le soleil !

b. ?Laissez le soleil entrer !

'Let the sun(light) in!'

Both sentences in (30) contain a non-volitional laissé, the sun, while the implicit laisseur is meant to be the reader of the ad. It is part of our knowledge of the world that the sun produces light. So, what we expect (3) to be is an invitation to let the light produced by the sun into our houses (potentially thanks to bigger windows, or new seethrough curtains). Yet, this is not what is encoded by (30b). While the sentence is in no 
way ungrammatical, it fails to express an invitation. The pre- $\mathrm{V}$ position for the laissé argument makes it more agentive, thus sounding like the sun is acting volitionally and wants to enter the house, although it is currently being blocked from doing so. (30b) reads as a command to remove said blocking, which is obviously infelicitous in an ad.

A closer look at the data, then, calls for a more precise characterisation. As regards the laissé, acceptability is constrained by the thematic selection of the embedded verb rather than by the semantic properties of the entity denoted by the NP per se. The generalisation we propose is that when the laisseur is not a proto-agentive subject itself, laissés are ruled out, no matter their position, whenever they are interpreted as protoagentive subjects of the embedded verb.

GEN3: Entities that are neither CAUSERS nor AGENTS (non-volitional and not selfenergetic) are acceptable as laisseurs if the laissé is also interpreted as acting non-volitionally.

Let's take stock. There are three points that are worth discussing after our descriptive survey. First, we have seen that self-generation of force is relevant to the extent that entities discharging the thematic role of CAUSERS are ruled out (see examples (19) and (20)). This being granted, what is common between proto-agentive, volitional AGENTS such as the laisseurs of (24) and (25), and the non-volitional, non-energetic subjects like the curtains of example (27)? In the following section, we argue that the common feature is that the force ascribed to the laisseur and laissé seems to be conceptualised rather as an intrinsic property attributed as a disposition, which can be either of psychological nature (volition) or based on functional (relative to the role of the participant in an event/state of affairs) or physical properties.

Next, the attribution of volitionality to the laisseur is relevant as it seems to discriminate roughly between the Pre- $\mathrm{V}$ or post-V positions of the laissé. Although acceptability data are blurred when both laisseur and laissé are agentive, when the laisseur is non-agentive judgements seem to be sharper. Is there a sense in which one of the two constructions is marked with respect to proto-agentivity?

The relevant data are summarised in table 1 below, where patterns are paired with the intuitive definition of the interpretation of the construction, as proposed by Enghels \& Roegiest (2012), as expressing authorisation or non-opposition.

Table 1. Summary on the properties of laisseur and laissé

\begin{tabular}{|c|c|l|l|}
\hline $\begin{array}{c}\text { Property of } \\
\text { laisseur }\end{array}$ & Property of laissé & Interpretation & Example \\
\hline \multicolumn{2}{|c|}{ Physical force } & $*$ & $(19 \mathrm{a}),(20 \mathrm{a})$ \\
\hline Volition & Volition & $\begin{array}{l}\text { authorise or } \\
\text { not-oppose }\end{array}$ & $\begin{array}{l}\text { (24a) authorise }- \text { pre-V favoured } \\
(24 \mathrm{~b}) \text { not-oppose }- \text { post-V favoured }\end{array}$ \\
\hline \multicolumn{2}{|c|}{ Physical force } & $*$ & $(19 \mathrm{~b}),(20 \mathrm{~b})$ \\
\hline $\begin{array}{c}\text { Physical/ } \\
\text { Functional ability }\end{array}$ & $\begin{array}{c}\text { Physical/ } \\
\text { Functional ability }\end{array}$ & not-oppose & $(27),(28 \mathrm{~b})$ - post-V favoured \\
\hline
\end{tabular}


We see from Table 1 that the Post-V construction seems to be marked, as its interpretation is more specific (not-oppose) also in the condition where both laisseur and laissé are volitional. In the next section, we are going to tackle the first issue mentioned above, and propose a way to characterise the distinction between physical forces and physical abilities in terms of an intensional property, a disposition.

\section{3 Intentions and dispositions}

As we have seen in section 3.2, corpus and elicited data show that laisser is never used to represent causative relations whenever the laisseur exerts a physical force on the laissé (cf. examples (19), (20) and also (31) below). It differs in this respect from other causative verbs, such as permettre ('allow'), which allows the subject of the causative predicate to be a prototypical causer (Alexiadou \& Schaefer 2008), i.e. an entity only capable to exert physical force (31a).
a. Le vent permet à l'éolienne de faire son boulot the wind allow.IMP the wind turbine to do its job 'The wind allows the wind turbine to do its job.'
b. \#Le vent laisse l'éolienne faire son boulot. the wind laisser.IMP the wind turbine do.INF its job

We thus submit the following hypothesis. We characterise laisser as an intentional verb, i.e. one where the causing force exerted by the laisseur is characterised as an intention, of which we give as a start the restricted definition in (32):

(32) intention: the tendency towards an endstate, ascribed to a class of entities with respect to the property $\mathrm{P}$ that defines the class.

The definition in (32) builds on the shared intuition that intentions are identified via their goals, and allows us to filter out from the class of intentions actions that are manifested by force-generating entities such as the wind or the tide. It includes tendencies inferred by interpreting both mental acts (e.g. acts of volition) and dispositional states, such as the built-in possibility of hindering or allowing a certain eventuality to happen granted to an entity on the basis of a regular inference. Thus, it is understood that Jean in (33) has manifested an intention with respect to the embedded event which is ascribed to Jean qua volitional entity capable of hindering the event by volition, whereas the curtains in (34) are understood as having a tendency to screen the light as a built-in intention qua manufactured objects with a specific function, but are defective in doing so. It is these dispositional properties that are relevant for Jean or the curtains to satisfy the felicity conditions of laisser: John may prevent the children from playing if he wants to, and the curtains may hinder the light from entering the room, although the sentence then asserts that they do not manifest this tendency in this specific case.

Jean a laissé les enfants jouer.

Jean laisser.PF the children play.INF

'Jean let the children play.' 
Les rideaux laissent passer la lumière.

the curtains laisser.IMP pass.INF the light

'The curtains let the light filter in.'

We thus may define intentions as a kind of dispositional properties. In the philosophical literature, "canonical" dispositions have been characterised as inherent properties in virtue of which an entity behaves in a certain way with respect to a given situation (Fara 2001). For instance, a sentence such as (35) ascribes to wind turbines the disposition to make electricity, and it is true only if wind turbines have an intrinsic property such that they produce electricity whenever hit by the wind. Importantly, this disposition is attributed to the device (and the proposition expressed by (35) deemed true) also if the wind turbine has never been put into use.

Wind turbines make electricity when hit by the wind.

Tendencies such as those for making electricity by the wind turbine rely, for their ascription to an entity, on the manifestation of a property $\mathrm{P}$ which is common to the general class of wind turbines. Dispositions are modal because their specification with respect to an entity in a world $w$ involves the satisfaction of a property in a different world w', that is, the world where they manifest themselves with respect to that entity. The assertive content of laisser specifies that the world of manifestation $\mathrm{w}^{\prime}$ is not the world where the assertion is true.

Defining dispositions as intensional properties provides a link to the characterisation of thematic selection. The characterisation of the proto-roles for the subject positions of the two verbs in laisser-causatives may be defined as clusters of dispositional properties attributed to event participants - let's call them causative dispositions. Causative dispositions are intrinsic properties in virtue of which entities can be given a role in a causal chain (see also Donazzan \& Tovena 2015). The characterisation of dispositions as intrinsic properties ascribed via a generalisation over classes of events and situations is responsible for the dispositional flavour of certain generic statements, such as (35), and also accounts for the restriction of certain types of subject instruments to predicates modified by non-episodic aspectual configurations. The device in (36) opens cans in virtue of its structural/physical dispositions; however, it can become a proper subject of the predicate only in a sentence where the simple present in French allows for a generic interpretation (36a), and keeps its instrumental role in episodic sentences characterised by the perfective aspect (passé composé) (36b-c).

(36) a. Cet outil ouvre les boîtes de conserve.

'This device opens food cans.'

b. $\quad$ \#Cet outil a ouvert la boîte de conserve.

'This device opened the food can.'

c. On a ouvert la boîte de conserve avec cet outil.

'We opened the food can with this device.' 
Let us give another example. Animacy (which is sometimes evoked in analysis of causative relations, see e.g. Enghels \& Roegiest 2012) is a categorial property, it can be attributed relative to a world of evaluation: an entity is animate (or not) in a certain world, just as it may be red or plastic-free in that world. There is no sense in which one may display animacy only relative to a situation.

$$
\lambda x \lambda w \text {. ANIMATE }(x, w) \text { iff } x \in[[\text { ANIMATE }]] w \rightarrow x \text { is an animate entity in } w
$$

In contrast, intention may be understood as a disposition in that it manifests itself (and can thus be ascribed to an entity) only relative to an event: one acts intentionally or not, just as one may be considered generous only when acting with prodigality. This is confirmed by cases such as (38). Suppose a context where the curators of an art gallery screened an ancient picture with special curtains that allow the visitors to catch sight of the picture while protecting it from the potential damage of being exposed to direct light. In this context, (38a), while contextually plausible, would be unfelicitous, as the verb regarder "to watch" seeks for an entity that manifests intentionality in its subject position (it is an activity verb); if the predicate allows for subjects that do not manifest intentionality, as it is the case for the perception verb apercevoir 'to catch sight', then animate entities are acceptable again (38b).

$$
\begin{aligned}
& \text { a. \#Les rideaux (fins) laissent les visiteurs regarder le tableau } \\
& \text { the curtains laisser.IMP the visitors watch.INF the picture } \\
& \text { b. Les rideaux (fins) laissent les visiteurs apercevoir le tableau } \\
& \text { the curtains laisser.IMP the visitors catch-sight.INF the picture } \\
& \text { 'The curtains let the visitors catch sight of the picture.' }
\end{aligned}
$$

Examples such as (38) show that it is not the property of the entity per se (animate or inanimate) that is relevant for its role in the construction, but rather the property that it manifests in the construction, which is determined, in the case of the laissé, by the selectional restrictions of the embedded predicate.

The linking of dispositions to thematic roles depends then on the fact that they are intensional properties generalised to classes of events and entities: given a predicate of events $\mathrm{P}$ and a predicate of individuals $\mathrm{Q}$, a disposition $\mathrm{D}$ is attributed to all $\mathrm{x}$ in $\mathrm{Q}$ relative to all $\mathrm{e}$ in $\mathrm{P}$. At the level of representation of argument structure, a verbal predicate selects for a given argument position a class of entities defined by a disposition, say the possibility of being self-generating force or to be volitional (Donazzan \& Tovena 2015). Generalising, we could say that predicates are possible manifestations of the disposition of their arguments.

Given our definition of the relevant property as an intention, we make Table 1 more precise below. 
Table 2. Summary of the type of intention, the interpretation and the syntactic pattern

\begin{tabular}{|l|l|l|l|l|}
\hline Pattern & Intention & $\begin{array}{l}\text { Type of } \\
\text { Intention }\end{array}$ & Interpretation & Example \\
\hline $\begin{array}{l}\text { Pre-V or } \\
\text { Post-V }\end{array}$ & Yes & Volition & $\begin{array}{l}\text { Authorise or } \\
\text { not-oppose }\end{array}$ & $\begin{array}{l}\text { Jean a laissé les enfants manger. } \\
\text { Jean laisser.PF the children eat } \\
\text { Jean a laissé manger les enfants } \\
\text { Jean laisser.PF eat the children }\end{array}$ \\
\hline $\begin{array}{l}\text { Post-V } \\
\text { favoured }\end{array}$ & Yes & $\begin{array}{l}\text { Physical or } \\
\text { Functional } \\
\text { Disp }\end{array}$ & Not-oppose & $\begin{array}{l}\text { Les rideaux laissaient filtrer la lumière } \\
\text { the curtains laisser.IMP filter the light }\end{array}$ \\
\hline
\end{tabular}

\section{Conclusions}

We have sought to present a more detailed account for the two constructions that the French causative verb laisser can enter, by drawing a mapping between structure and conceptual representation using Talmy's force dynamics model of causation. Additionally, this allowed us to show that the constraints on the argument selection of laisser can be explained using causal dispositions.

Let us stress, as a concluding remark, that on a descriptive level our intuition is not completely new. For example, for causative lexical verbs such as faire/make, encoding a prototypical CAUSE relation in Dowty's terms, the definition of a prototypical Causer has been sometimes given in terms of properties such as volitionality and self-generation of force (see e.g. Folli \& Harley 2008). These accounts, however, did not suggest a characterisation of such properties as dispositions.

Also, one important point for the present case is that we consider dispositions as properties, not physical forces. This helps us establish the link between forces in the conceptual representation of the causative chain and the properties denoted by the NPs in its linguistic realisation. We assume the following articulation for the three levels of representation of a causative relation into a causative structure.

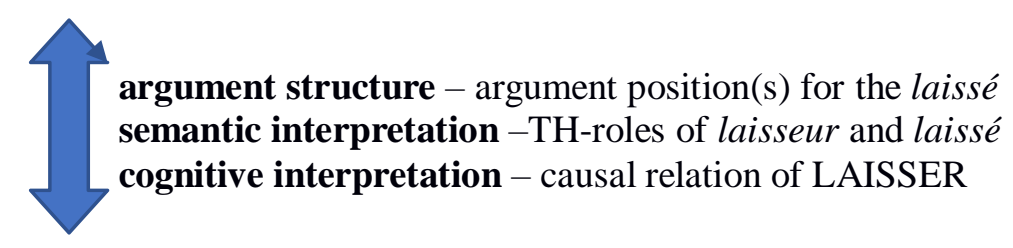

This characterisation thus captures the empirical fact that laisser, contrary to faire, is not properly dynamic: the laisseur of a laisser-construction is either a decider (it gives authorisation, thereby indirectly allowing the laissé to independently make the event occur) or it simply does not oppose the force exerted by the laissé. Although an authorisation could be seen as a sort of speech act, in both cases the laisseur does not act 
physically (hence, the non-dynamicity of laisser) ${ }^{6}$. If dispositions are conceptualised as intentions, however, laisser originates a conceptual dynamic configuration; it has been shown that intentions are perceived as forces in volitional entities (Wolff 2003) and we may venture the hypothesis that they are conceptualised as forces also in intentional objects.

Finally, the behaviour of laisser (and possibly, of its counterparts in Romance languages, see Enghels \& Roegiest 2012) provides a new perspective on causation as a concept and its primitives. Indeed, as mentioned above, some philosophical approaches to causation have mostly presented it as a counterfactual relation between events (Lewis 1974), thus making it impossible to discriminate between make-causatives and letcausatives. Even though force dynamics (as defined by Talmy) have brought in a more fine-grained division of causative primitives, his categorisation is still not refined enough to account for the range of interpretations yielded by laisser-causatives. Adding grammatical constraints and dispositions to force theory will allow us to develop a model that accommodates the different realisations of laisser.

\section{References}

Abeillé, A., Godard, D. and Miller, P. 1997. Les causatives en français, un cas de compétition syntaxique. Langue française 115: 62-74.

Alexiadou, A. and Schaefer, F. 2008. Instrument subjects are agents or causers. In D. Baumer, D. Montero \& M. Scanlon (eds.), Proceedings of the 25th West Coast Conference on Formal Linguistics, 40-49. Somerville, MA: Cascadilla Proceedings Project.

Alsina, A. 1992. On the argument structure of causatives. Linguistic Inquiry 23: 517-555.

Authier, J. M. \& Reed, L. 1991. Ergative predicates and dative cliticization in French causatives. Linguistic Inquiry 22 (1): 197-205.

Borel, M. 1972. Sémantique des factitives en français. MA dissertation, Université Paris 8 - Vincennes St Denis.

Bourdet, É. 1931. Le sexe faible. Paris: Stock (Delamain et Boutelleau)

Butt, M. 1995. The Structure of Complex Predicates in Urdu. PhD dissertation, Stanford University.

Butt, M. 2010. The light verb jungle: Still hacking away. In M. Amberber, B. Baker \& M. Harvey (eds.), Complex Predicates: Cross-Linguistic Perspectives on Event Structure, 48-78. Cambridge: Cambridge University Press.

Copley, B. \& Harley, H. 2015. A force-theoretic framework for event structure. Linguistics and Philosophy 38: 103-158.

Davis, W. 2019. Implicature. In E. Zalta (ed.), The Stanford Encyclopedia of Philosophy Stanford, CA: CSLI, (Fall 2019 Edition). <https://plato.stanford.edu/archives/fall2019/entries/implicature/>.

Donazzan, M. \& Tovena, L. 2015. Dispositions in event nouns: Decomposing the agentivity constraint. In F. Martin, M. Pitteroff \& T. Pross (eds.), Morphological, Syntactic and Semantic Aspects of Dispositions, 65-84. SinSpec Series of SFB732, University of Stuttgart.

Dowty, D. 1979. Word Meaning and Montague Grammar. Dordrecht: D. Reidel.

Dowty, D. 1991. Thematic proto-roles and argument selection. Language 67 (3): 547-619.

Enghels, R. \& Roegiest, E. 2012. Los verbos de causación negativa dejar y laisser: Sintaxis y polisemia. In V. Bellosta von Colbe \& M. García García (eds.), Aspectualidad - Transitividad - Referencialidad. Las lenguas románicas en contraste, 87-117. Frankfurt a. M.: Peter Lang.

Fara, M. 2001. Dispositions and their Ascription. PhD dissertation, Princeton University.

\footnotetext{
${ }^{6}$ This is why we characterise one of the two interpretations as authorise, rather than allow, contra Enghels \& Roegiest's original proposal. While allow is a verb of enabling that may imply a physical force, laisser excludes force exertion, as shown by the fact that prototypical CAUSER arguments are excluded. Authorise captures the volitional feature of laisser.
} 
Folli, R. \& Harley, H. 2007. Causation, obligation, and argument structure: On the nature of little v. Linguistic Inquiry 38 (2): 197-238.

Folli, R. \& Harley, H. 2008. Teleology and animacy in external arguments. Lingua 118 (2): 190-202.

Guasti, M. 1996. Semantic restrictions in Romance causatives and the Incorporation Approach. Linguistic Inquiry 27 (2): 294-313.

Kayne, R. 1975. French Syntax: The Transformational Cycle. Cambridge, MA: MIT Press.

Lewis, D. 1974. Causation. The Journal of Philosophy 70 (17): 556-567.

Maldonado, R. 2007. Soft causatives in Spanish. In N. Delbecque \& B. Cornillie (eds.), On interpreting Construction Schemas, 229-260. Berlin, New York: Mouton de Gruyter.

Martineau, F. 1990. La construction 'accusatif avec infinitif' avec les verbes causatifs et de perception en moyen français. Revue québécoise de linguistique 19 (1): 77-100.

Mauriac, F. 1932. Le noeud de vipères. Paris: Grasset.

McGrath, S. 2005. Causation by omission: A dilemma. Philosophical Studies 123 (1-2): 125-148.

Mumford, S. \& Anjum, R. 2013. Causation: A Very Short Introduction. Oxford: Oxford University Press.

Potts, C. 2015. Presupposition and implicature. In S. Lappin \& C. Fox (eds.), The Handbook of Contemporary Semantic Theory, 2nd edition, 168-202. Oxford: Wiley-Blackwell.

Rizzi, L. 1978. A restructuring rule in Italian syntax. In S. Keyser (ed.), Recent Transformational Studies in European Languages, 113-158. Cambridge, MA: MIT Press.

Soares da Silva, A. 1998. Prototipicidad y cambio semántico: El caso ibérico de deixar/dejar. In J. L. Cifuentes Honrubia (ed.), Estudios de Lingüística Cognitiva 1: 279-294. Alicante: Universidad de Alicante.

Soares da Silva, A. 2003. Image schemas and category coherence: The case of the Portuguese verb deixar. In H. Cuyckens, R. Dirven \& J. R. Taylor (eds.), Cognitive approaches to lexical semantics, 281-322. Berlin/Boston: De Gruyter Mouton.

Soares da Silva, A. 2004. Verbos y construcciones causativas analíticas en portugués y en español. Estudios de Lingüística: El Verbo 581-598.

Talmy, L. 1988. Force dynamics in language and cognition. Cognitive Science 12: 49-100.

Wolff, P. 2003. Direct causation in the linguistic coding and individuation of causal events. Cognition 88: 1-48.

Wolff, P. \& Song, G. 2003. Models of causation and the semantics of causal verbs. Cognitive Psychology 47: 276-332.

Wolff, P. \& Thorstad, J. 2016. Force dynamics. In M. Waldmann (ed.), Oxford Handbook of Causal Reasoning, 147-168. Oxford: Oxford University Press. 
